\title{
Multi-metal resistance and potential of Alcaligenes sp. MMA for the removal of heavy metals
}

\author{
Kushneet Kaur Sodhi ${ }^{1} \cdot$ Mohit Kumar $^{1,2} \cdot$ Dileep Kumar Singh $^{1}$ (])
}

Received: 16 June 2020 / Accepted: 22 September 2020 / Published online: 26 October 2020

(c) Springer Nature Switzerland AG 2020

\begin{abstract}
Pollution of water bodies is increasing because of toxic metals. In view of this, the present study examines the removal efficiency of heavy metals $\mathrm{Cu}^{2+}, \mathrm{Cd}^{2+}, \mathrm{Cr}^{6+}, \mathrm{Ni}^{2+}$, and $\mathrm{Zn}^{2+}$ by a bacterial strain isolated from River Yamuna. Initially, three strains were isolated, and further examined for the maximum tolerance index. Among the three isolates, strain MMA showed the highest tolerance to the heavy metals and was selected. The biochemical characterization and phylogenetic analysis based on $16 \mathrm{~S}$ rRNA gene sequencing showed that the strain belonged to the genus Alcaligenes. Metal removal by the strain was observed at $20 \mathrm{mg} / \mathrm{L}$ in both individual and multi-metal experimental setup. The highest metal removal within $72 \mathrm{~h}$ was observed for $\mathrm{Cu}^{2+}(88.45 \%)$ followed by $\mathrm{Ni}^{2+}(82.45 \%), \mathrm{Zn}^{2+}(69.99 \%), \mathrm{Cd}^{2+}(63.04 \%)$, and least for $\mathrm{Cr}^{6+}$ (48.93\%). Bacterial biosorption studies were done using SEM-EDX and FT-IR. Along with the metal removal, the heavy metal assessment of the River was also done for the year September 2017-August 2018, representing the post-monsoon, monsoon, and pre-monsoon. $\mathrm{Cu}^{2+}, \mathrm{Cd}^{2+}, \mathrm{Cr}^{6+}$, and $\mathrm{Zn}^{2+}$ were detected in the water sample due to the uncontrolled discharge of effluents into the river.
\end{abstract}

Keywords Alcaligenes sp. Bioaccumulation · FTIR $\cdot$ Heavy metals $\cdot$ SEM-EDX

\section{Introduction}

Accumulation of heavy metals in the aquatic ecosystem poses a serious risk to aquatic flora and fauna [31]. The subsequent enrichment via food chains further puts human health at risk [18]. Heavy metals also affect the microbial diversity, growth, morphology by disrupting the cell membrane integrity and denaturation of the cellular proteins, thereby disturbing the aquatic processes mediated by the microbes $[22,42]$. Human exposure to heavy metals is associated with diseases such as cancer, damage to the organs, and death [16]. The aquatic environment, along with sediments and soil, plays a major role in biogeochemical cycles, and its pollution leads to disturbance of the ecological balance [17].

The present study focusses on the River Yamuna. The Yamuna River is the most important source of water for the northern parts of India. The River stretch is $48 \mathrm{~km}$ in length [6]. Almost $95 \%$ of the River water is used as a source of irrigation, remaining is used in the industries and household [11]. Assessment of water quality of the River was done in the study conducted by Bhattacharya et al. [6]. High levels of hazardous metals were found and various drains that emerge into the Yamuna are the main source of pollution. The irrigation through this polluted water leads to heavy metals contamination in crops and soil. Metals such as

Electronic supplementary material The online version of this article (https://doi.org/10.1007/s42452-020-03583-4) contains supplementary material, which is available to authorized users.

Dileep Kumar Singh, dileepksingh@gmail.com | ${ }^{1}$ Soil Microbial Ecology and Environmental Toxicology Laboratory, Department of Zoology, University of Delhi, New Delhi, Delhi 110007, India. ${ }^{2}$ Department of Zoology, Hindu College, University of Delhi, New Delhi, Delhi 110007, India. 
$\mathrm{Pb}^{2+}, \mathrm{Cu}^{2+}, \mathrm{Cr}^{6+}, \mathrm{Ni}^{2+}, \mathrm{Cd}^{2+}$, and $\mathrm{Zn}^{2+}$ were above the permissible limits set by the Food and Agricultural Organisation (FAO). Heavy metals are frequently discharged into the environment via the use of fertilizers, textile industries, pesticides, and irrigation via contaminated water [2]. The River plays a vital role in the local chores of people living in nearby areas. The rapid surge in the population, accompanied by the industrialization has led to river pollution. Although the heavy metals act as enzyme cofactors, most of them are toxic at low concentrations [35].

Concerns over the contamination of the water bodies with heavy metals have led to the development of remediation strategies to reduce the toxicity of the metal in the environment. Physical and chemical methods of remediation produce a large amount of sludge and also are not cost-effective. Over the years, the bioremediation of $\mathrm{HM}$ has received considerable importance as the use of microorganisms is eco-friendly and cost-effective and provides a sustainable alternative over the physico-chemical treatments [3,24]. Microbes have adapted to tolerate the metal stress either by the efflux of metals, complexation, and reduction of metals and use the metals in anaerobic respiration as an electron receptor [30, 32]. Microbial flocculant is used for the removal of $\mathrm{Pb}^{2+}$ ions from the aqueous solution, and the efficiency was reached up to $99.85 \%$ [29]. Pseudomonas sp. $\mathrm{CH} 6$ and Herbaspirillium sp. $\mathrm{CH} 13$ removed $78 \%$ of $\mathrm{Hg}^{2+}$ and $66 \%$ of $\mathrm{Cd}^{2+}$ from the solution. Alcaligenes faecalis is reported to detoxify $\mathrm{Cd}^{2+}, \mathrm{Pb}^{2+}$, and $\mathrm{Hg}^{2+.} \mathrm{Cd}^{2+}$ is removed from the supernatants and is accumulated in the pellets of the bacterial cell [13]. Microbes resistant to metals have been isolated from the contaminated sites and studies on the interactions between microbes and heavy metals focus on microbial transformation and conversion of the toxic metal into a less toxic form by reduction $[13,14]$.

The current scenario demands an effective and ecofriendly approach to tackling heavy metal pollution. In this context, the present study was aimed to isolate and characterize the multi-metal resistant bacterial strain, studying its bioaccumulation characteristics and the use of FTIR and SEM-EDX to reveal the possible biosorption mechanism of the bacterial strain. Briefly, a bacterium isolates having the potential for multiple metal removal has been discussed.

\section{Materials and methods}

\subsection{Preparation of metal stock solution}

Stock solutions of $1000 \mathrm{mg} / \mathrm{L}$ were prepared by dissolving respective metal salts cadmium nitrate $\left[\mathrm{Cd}\left(\mathrm{NO}_{3}\right)_{2}\right]$, potassium dichromate $\left[\mathrm{K}_{2} \mathrm{Cr}_{2} \mathrm{O}_{7}\right]$, copper nitrate $\left[\mathrm{Cu}\left(\mathrm{NO}_{3}\right)_{2}\right]$, nickel nitrate $\left[\mathrm{Ni}\left(\mathrm{NO}_{3}\right)_{2}\right]$, and zinc nitrate $\left[\mathrm{Zn}\left(\mathrm{NO}_{3}\right)_{2}\right]$ in double distilled water, and diluted before experimental use. Deionized ultra-pure water (RIONS Ultra 370 series) was used. For all the standards, chemicals were obtained from Merck, Germany.

\subsection{Heavy metal assessment in River Yamuna}

$\mathrm{Cu}^{2+}, \mathrm{Cd}^{2+}, \mathrm{Cr}^{6+}, \mathrm{Ni}^{2+}$, and $\mathrm{Zn}^{2+}$ were analyzed in Yamuna River water sample $\left(28^{\circ} 40^{\prime} 5.53^{\prime \prime} \mathrm{N}, 77^{\circ} 15^{\prime} 0.35^{\prime \prime} \mathrm{E}\right)$ in postmonsoon (September 2017-December 2017), pre-monsoon (February 2018-June 2018), and monsoon (August 2018) after acid digestion with concentrated nitric acid (65\%) in the ratio of 1:10 in a micro wave digester and then filtered through Whatman No. 1 filter paper [15]. Quantification of the samples was done by atomic absorption spectroscopy (AAS) (pg instruments UK).

\subsection{Water sample collection and bacterial isolation}

Water samples were collected from River Yamuna $\left(28^{\circ} 40^{\prime}\right.$ $5.53^{\prime \prime} \mathrm{N}, 77^{\circ} 15^{\prime} 0.35^{\prime \prime} \mathrm{E}$ ) and stored at $4^{\circ} \mathrm{C}$ till further use. The water samples were diluted to $10^{-10}$ times in $0.1 \%$ phosphate buffered saline (PBS, pH 7.4) and spread plating was done on Luria Broth (LB agar) plates amended with $100 \mathrm{mg} / \mathrm{L}$ of the multi-metal mixture containing $20 \mathrm{mg} / \mathrm{L}$ each of $\mathrm{Cu}^{2+}, \mathrm{Cd}^{2+}, \mathrm{Cr}^{6+}, \mathrm{Ni}^{2+}$, and $\mathrm{Zn}^{2+}$ and incubated at $28^{\circ} \mathrm{C}$ for $48 \mathrm{~h}$. Morphologically distinct colonies that could resist the multi-metal stress were picked up, and the bacterial colonies were purified by repeated streaking and restreaking. Three distinct colonies were purified and named as MMA, MMA1, and MMA 2 were checked for the metal tolerance at increasing multi-metal concentration.

\subsection{Metal tolerance index of the bacteria}

The strains were grown in LB at different concentrations of heavy metals ranging from 25 to $300 \mathrm{mg} / \mathrm{L}$ along with the control. Metal containing media was inoculated with bacterial strains and was incubated at $28^{\circ} \mathrm{C}$ at $150 \mathrm{rpm}$, and growth was monitored for 5 days after every $24 \mathrm{~h}$. To determine the metal tolerating index of the bacteria, the bacteria were inoculated on the LB agar plates amended with an appropriate amount of $300 \mathrm{mg} / \mathrm{L}$ total $\mathrm{Cr}^{6+}, \mathrm{Cu}^{2+}$, $\mathrm{Ni}^{2+}, \mathrm{Zn}^{2+}$, and $\mathrm{Cd}^{2+}$. The plates were incubated for 3 days at $28^{\circ} \mathrm{C}$. The experiment was done in triplicates. Biotic control was used without metal, and the tolerance index was evaluated by measuring the radius of the colony (in $\mathrm{cm}$ ) against the biotic control. The radius was calculated by the ratio of the radius of the metal-laden colonies to the radius of untreated colony, i.e., $T_{\mathrm{i}}=R_{\mathrm{m}} / R_{\mathrm{c}}$, where $T_{\mathrm{i}}=$ tolerance index; $R_{\mathrm{m}}=$ radius of the metal treated colony; $R_{\mathrm{c}}=$ radius of the control colony [10]. 


\subsection{Identification of the isolated strain}

\subsubsection{Biochemical tests}

The biochemical characterization was done using $\mathrm{KB} 003 \mathrm{Hi}-$ Media kit $\mathrm{Hi} 25$ for phenotypic characterization of the bacterial strain. $50 \mu \mathrm{L}$ inoculums of $18-24 \mathrm{~h}$ culture of the bacteria were added and incubated for $24 \mathrm{~h}$. The color change which was observed after $24 \mathrm{~h}$ of incubation was accounted for positive or negative result. Bergey's manual of determinative bacteriology 1989 was used to check the compatibility of the biochemical test and morphological tests with the BLAST results and closest phylogenetic neighbor [23].

\subsubsection{Molecular characterization of the strain using $16 \mathrm{~S}$ rRNA gene sequencing}

The universal primers of bacteria 27F (5'-AGAGTTTGATCMTGGCTCAG-3') and 1492R (5'-TACGGCTACCTTGTTACG ACTT-3') [36] were used for amplification in a thermocycler (Bio-Rad, India). The reaction mixture of $25 \mu \mathrm{L}$ contained $7 \mu \mathrm{L}$ of template (50-100 ng), $27 \mathrm{~F} \& 1492 \mathrm{R} 2.5 \mu \mathrm{L}$ each $(0.4 \mu \mathrm{M}), 2 \mu \mathrm{L}$ dNTPs (200 $\mu \mathrm{M}$ each), $2.5 \mu \mathrm{L}$ reaction buffer (1X), $0.5 \mu \mathrm{L}$ Taq polymerase $\left(0.06 \mu \mathrm{L}^{-1}\right)$ and the volume was adjusted to $25 \mu \mathrm{L}$ by nuclease-free water. The PCR protocol followed included initial denaturation at $94{ }^{\circ} \mathrm{C}$ for $5 \mathrm{~min}$ which is followed by 35 cycles at $94^{\circ} \mathrm{C}$ for $30 \mathrm{~s}, 50^{\circ} \mathrm{C}$ for $30 \mathrm{~s}, 72^{\circ} \mathrm{C}$ for $90 \mathrm{~s}$, final extension at $72^{\circ} \mathrm{C}$ for $7 \mathrm{~min}$ and infinite hold at $4{ }^{\circ} \mathrm{C}$. $1 \%$ agarose gel was used to run amplified PCR product and the band of $1.5 \mathrm{~Kb}$ was eluted, purified, and sent for commercial sequencing. EZ taxon database was used to know the similarity of the bacterial strains [44], the sequences were aligned using MUSCLE in MEGA X, the tree was constructed by Neighbor-Joining method [34] using Maximum Likelihood model [38] and tree topology was estimated using the Bootstrap value of 1000 .

\subsection{Bioaccumulation of heavy metals by the bacterial strain}

Bioaccumulation studies were performed in $100 \mathrm{~mL} L B$ medium inoculated with Alcaligenes sp. MMA incubated at $28^{\circ} \mathrm{C}$ at $150 \mathrm{rpm}$. The medium was amended with $20 \mathrm{mg} / \mathrm{L}$ of individual metal. The bioaccumulation experiments were performed according to the permissible metal limits set by the FAO, as well as their occurrence in the river. Each $10 \mathrm{~mL}$ sample was aseptically taken from the flask at 24,48 , and $72 \mathrm{~h}$ and centrifuged at $9000 \mathrm{rpm}$ for $10 \mathrm{~min}$. The supernatant and pellet were separated, and the supernatant was subjected to digestion $160 \pm 4{ }^{\circ} \mathrm{C}$ for 20 min analyzed for metal ions via AAS. Abiotic control and biotic controls were also run in parallel. The dry weight of the biomass was measured using the gravimetric method. The mass of pellets was estimated, and contents were filtered on Whatman No. 1 filter paper which was dried before filtration and then weighed followed by drying overnight at $65^{\circ} \mathrm{C}$. The experiment was performed in triplicates. The amount of metal accumulation by the bacterial strain was calculated using the difference between the initial concentration and the concentration remaining in the supernatant. The specific uptake capacity $\left(q_{\mathrm{m}}\right)$ and uptake yield (\%) were calculated.

Uptake yield (\%) or \% metal removal $=($ Total metal ion concentration - residual metal ion concentration)/Total metal ion concentration $\times 100$

Specific uptake capacity $\left(q_{m}\right)=$ Heavy metal removed after days $(\mathrm{mg} / \mathrm{L}) /$ Dried biomass $(\mathrm{g} / \mathrm{L})$

\subsection{Morphological analysis}

\subsubsection{Scanning electron microscopy energy-dispersive X-ray spectroscopy (SEM-EDX)}

To check the alteration in the morphology on the bacterial cell surface after heavy metal stress, cells are grown in the $20 \mathrm{mg} / \mathrm{L}$ of $\mathrm{Cu}^{2+}, \mathrm{Cd}^{2+}, \mathrm{Cr}^{6+}, \mathrm{Ni}^{2+}$, and $\mathrm{Zn}^{2+}$ along with abiotic control. After $24 \mathrm{~h}$, the cultures were centrifuged at $10,000 \mathrm{rpm}$ for $5 \mathrm{~min}$ and the pellet was washed with PBS $(0.1 \mathrm{M})$ to remove the heavy metal from the suspension. The pellet was fixed with $2.5 \%$ glutaraldehyde overnight and then washed three times with PBS (pH 7.2) followed by serial dilution with $30 \%, 50 \%, 70 \%, 90 \%$, and $100 \%$ ethanol (Merck) and then given in USIC, Delhi University for SEM analysis. SEM was performed via ZEISS to observe the cell morphology alteration due to the binding of metal ions. The metal ion's presence on the bacteria was observed via EDX.

\subsubsection{Fourier transform infrared spectroscopy (FTIR)}

The functional groups responsible for metal uptake were analyzed by FTIR (Thermo Scientific Nikon I 50). Heavy metal concentration $20 \mathrm{mg} / \mathrm{L}$ (individual metal and multi-metal) and as well as biotic control were taken into consideration for FTIR. FTIR was done in the range of $650-4000 \mathrm{~cm}^{-1}$. Overnight bacterial cultures amended with individual metals were centrifuged and the pellet was lyophilized, $1 \mathrm{mg}$ of the bacterial pellet was mixed with $100 \mathrm{mg} \mathrm{KBr}$ powder, and analyzed using FTIR. 


\section{Results}

\subsection{Heavy metal assessment of River Yamuna}

The heavy metal assessment was done and the amount of heavy was estimated using AAS in all the three seasons for the year 2017-2018. Table 1 and Fig. 1 show the concentration of metals along with the permissible limit as set by $\mathrm{FAO} . \mathrm{Ni}^{2+}$ remains undetected in all three seasons. $\mathrm{Cu}^{2+}$ and $\mathrm{Zn}^{2+}$ were not detected in post-monsoon, whereas it is found within the permissible limit in premonsoon and monsoon. $\mathrm{Cd}^{2+}$ was above the permissible limit in all three seasons, $\mathrm{Cr}^{6+}$ except for the post-monsoon was above the permissible limit in pre-monsoon and monsoon. The concentration of $\mathrm{Cu}^{2+}$ was below the permissible limit in the pre-monsoon and monsoon. $\mathrm{Zn}^{2+}$ was also detected under the permissible limits. $\mathrm{Cu}^{2+}$ is not detected post-monsoon which might be due to the dilution of the river water. The major source of $\mathrm{Cu}^{2+}$ is the electroplating industries at Wazirabad near the banks of the river. $\mathrm{Cd}^{2+}$ is above the permissible limit (0.01 ppm) in all the three seasons. $\mathrm{Cd}^{2+}$ contamination is contributed mainly by the industrial processes which use $\mathrm{Cd}^{2+}$ for metal coating and making of batteries of $\mathrm{Cd}-\mathrm{Ni}$ [6]. $\mathrm{Cr}^{6+}$ was detected in all the three seasons and postmonsoon the concentration was lesser which might be due to the dilution of the river after the monsoon. $\mathrm{Cr}^{6+}$ contamination is attributed mainly to the electroplating industries. In our study, $\mathrm{Ni}^{2+}$ remains undetected in all the seasons in the year 2018, but according to the reports of Bhattacharya et al. [6], the $\mathrm{Ni}^{2+}$ was detected at this in the year 2013. $\mathrm{Zn}^{2+}$ was also detected under the permissible limits, sewage effluents mainly contribute to the presence of $\mathrm{Zn}^{2+}$ in water bodies.

\subsection{Isolation and maximum tolerance index (TI) of the bacterial isolates}

Using the shake flask enrichment method, the bacteria were isolated from the River Yamuna. Initially three bacteria were isolated and named as MMA, MMA1, and MMA2. The maximum tolerance index of the bacterial strains was studied at $300 \mathrm{mg} / \mathrm{L}$ concentration of individual metals in the LB agar plates (Fig. 2). The tolerance index was calculated and it was found only bacterial strain MMA was able to grow in the plates amended with $300 \mathrm{mg} / \mathrm{L}$ of copper and zinc showed growth and the TI was found to be $\mathrm{Cu}^{2+}$
Table 1 Heavy metal assessment of River Yamuna

\begin{tabular}{lllll}
\hline Heavy metal & $\begin{array}{l}\text { Pre monsoon (Febru- } \\
\text { ary 2018-June 2018) }\end{array}$ & Monsoon (Aug 2018) & $\begin{array}{l}\text { Post monsoon (Sep } \\
\text { 2018-Dec 2018) }\end{array}$ & $\begin{array}{l}\text { Permissible } \\
\text { limit (FAO) } \\
\text { ppm }\end{array}$ \\
\hline $\mathrm{Cu}$ & $0.015 \pm 0.0022$ & $0.011 \pm 0.0019$ & Not detected & 0.2 \\
$\mathrm{Cd}$ & $0.173 \pm 0.00007$ & $0.086 \pm 0.0002$ & $0.036 \pm 0.0005$ & 0.01 \\
$\mathrm{Cr}$ & $0.338 \pm 0.0002$ & $0.241 \pm 0.0002$ & $0.088 \pm 0.0002$ & 0.1 \\
$\mathrm{Ni}$ & Not detected & Not detected & Not detected & 0.2 \\
$\mathrm{Zn}$ & $0.598 \pm 0.0114$ & $0.106 \pm 0.0004$ & Not detected & 2 \\
\hline
\end{tabular}

Fig. 1 Concentration $\left(\mathrm{mg} \mathrm{L}^{-1}\right)$ of HMs in pre monsoon, monsoon and post monsoon in the year (2018)

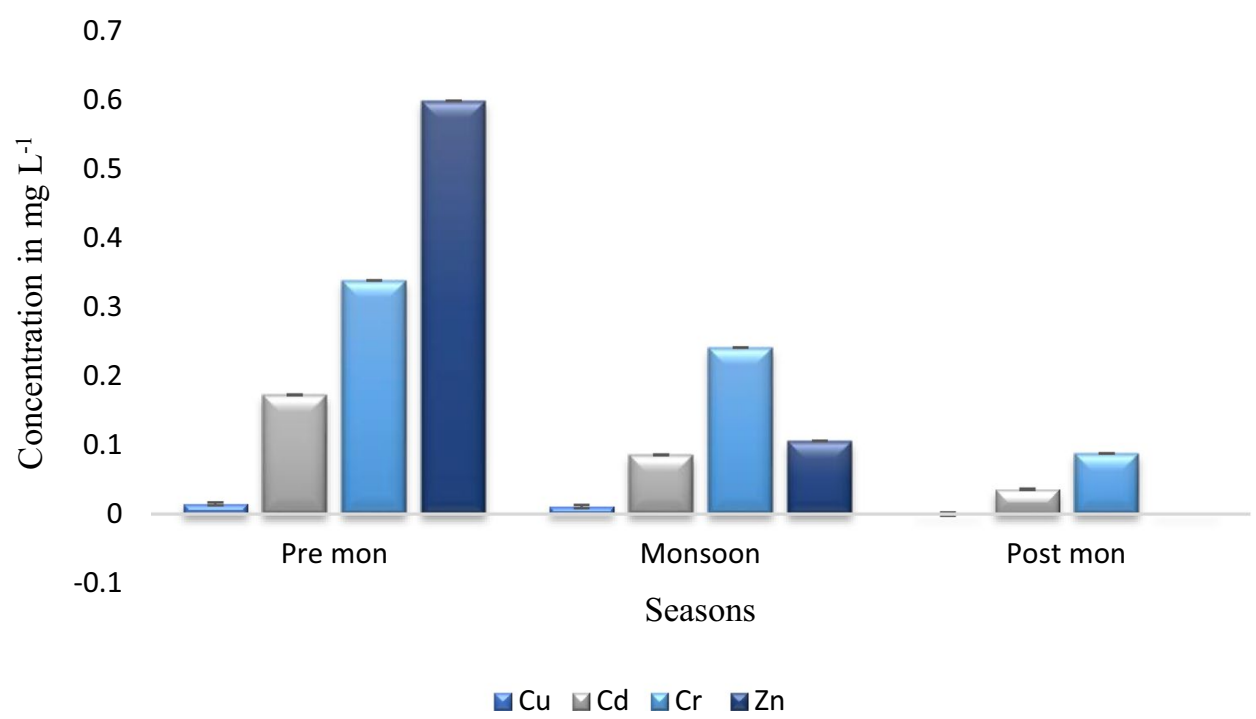




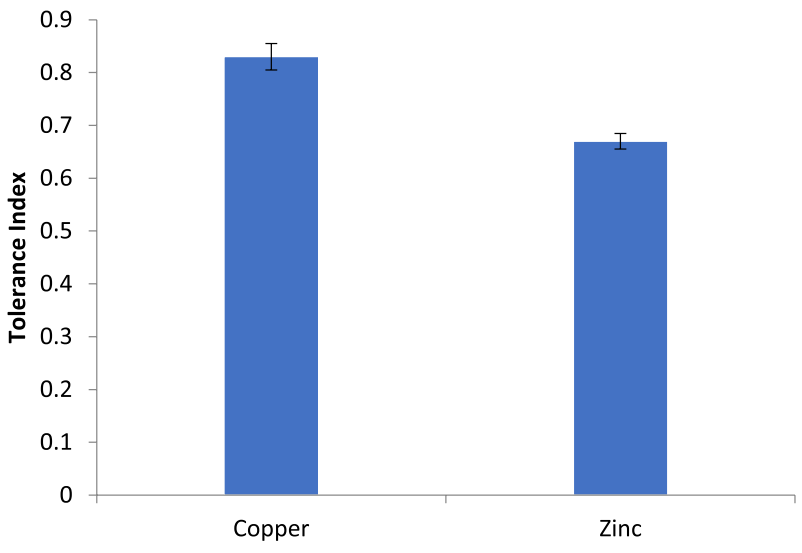

Fig. 2 Metal tolerance index of the Alcaligenes sp. MMA

$(0.83 \pm 0.025)$ and $\mathrm{Zn}^{2+}(0.67 \pm 0.015)$. The strain showed the lowest toxicity to the $\mathrm{Cu}^{2+}$, followed by $\mathrm{Zn}^{2+}$ and $\mathrm{Cd}^{2+}$, $\mathrm{Cr}^{6+}$, and $\mathrm{Ni}^{2+}$ is extremely toxic to the strain at $300 \mathrm{mg} / \mathrm{L}$, whereas the bacterial strains (MMA1, MMA2) were unable to tolerate the high metal stress (Fig. 1S).

\subsection{Identification of the bacterial isolates}

Based on the maximum tolerance index, strain MMA was able to tolerate and survive $300 \mathrm{mg} / \mathrm{L}$ concentration of $\mathrm{Cu}^{2+}$ and $\mathrm{Zn}^{2+}$ and was characterized as Alcaligenes sp. MMA using biochemical test and 16S rRNA gene sequencing.

\subsubsection{Biochemical test results}

For the biochemical tests, the KB003 kits were used, the result is summarized in Table 2 .

\subsubsection{S rRNA gene sequencing and phylogenetic analysis}

Based on 16S rRNA gene sequencing, the strain MMA showed $99.93 \%$ similarity with Alcaligenes faecalis strain J481.The phylogenetic tree for Alcaligenes sp. MMA is shown in Fig. 3. GenBank accession numbers for the strains were obtained as MH 973170 . The neighbor-Joining Method was used to infer the evolutionary history [34]. Maximum Likelihood Method was used as a model for tree construction. Evolutionary analyses were conducted in MEGA X [38].

\subsection{Bioaccumulation of heavy metal and effect of heavy metal on the metal uptake by Alcaligenes sp. MMA}

Figure 4 shows the metal removal by the Alcaligenes sp. MMA. The maximum metal removal was observed
Table 2 Biochemical test of strain MMA ' + ' indicates positive (more than 90\%), "indicates negative (more than 90\%), ' $\mathrm{V}$ ' indicates (11$89 \%$ positive)

\begin{tabular}{lc}
\hline Biochemical tests & MMA \\
\hline Oxidase & + \\
ONPG & - \\
Lysine utilization & - \\
Ornithine utilization & - \\
Urease & - \\
Phenylalanine deamination & - \\
Nitrate reduction & - \\
H2S production & - \\
Citrate utilization & + \\
Voges Proskaueuer's & - \\
Methyl Red & - \\
Indole production & - \\
Malonate utilization & $\checkmark$ \\
Esculin hydrolysis & - \\
Arabinose utilization & - \\
Xylose utilization & - \\
Adonitol utilization & - \\
Rhamnose utilization & - \\
Cellobiose utilization & - \\
Mellobiose utilization & - \\
Sachharose utilization & - \\
Raffinose utilization & - \\
Trehalose utilization & - \\
Lactose utilization & - \\
Catalase production & - \\
\hline & - \\
\hline
\end{tabular}

Based on \% strain showing reactions following symbols have been assigned from laboratory results and standard references. $+=$ Positive $($ more than $90 \%)=$ Negative $($ more than $90 \%) \mathrm{V}=11-89 \%$ positive

at $20 \mathrm{mg} / \mathrm{L}$ for $\mathrm{Cu}^{2+}(88.45 \%)$ followed by $\mathrm{Ni}^{2+}(82.45 \%)$, $\mathrm{Zn}^{2+}(69.99 \%), \mathrm{Cd}^{2+}(63.04 \%)$ and least for $\mathrm{Cr}^{6+}(48.93 \%)$, whereas the biomass trend was not the same as followed by the metal removal, the maximum biomass at the end of $72 \mathrm{~h}$ was observed for $\mathrm{Ni}^{2+}(4.0 \mathrm{~g} / \mathrm{L})$ followed by $\mathrm{Cu}^{2+}$ $(2.6 \mathrm{~g} / \mathrm{L}), \mathrm{Cr}^{6+}(0.4 \mathrm{~g} / \mathrm{L})$ and $\mathrm{Zn}^{2+}(0.4 \mathrm{~g} / \mathrm{L})$, and least for $\mathrm{Cd}^{2+}(0.2 \mathrm{~g} / \mathrm{L})$, whereas in the biotic control it was $4.6 \mathrm{~g} / \mathrm{L}$. The previous studies by Gola et al. [20, 21], also showed that the heavy metal removal by fungi is not directly correlated with biomass production. The biomass was highest in the case of $\mathrm{Ni}^{2+}$ and $\mathrm{Cu}^{2+}$ stress when compared to the biotic control, $\mathrm{Cu}^{2+}$ is less toxic than other heavy metals for the bacterial strain, which is supported by significant metal removal, $\mathrm{Cr}^{6+}$ removal is the least in $72 \mathrm{~h}$. In $\mathrm{Cr}^{6+}$ polluted environment, microbes adapt themselves to have effective systems to neutralize the toxic effects of chromate [28], although it was not observed in the case 
Fig. 3 Neighbor joining method was used to infer the evolutionary history [34]. Maximum Likelihood Method was used as a model. Evolutionary analyses were conducted in MEGA X [38]

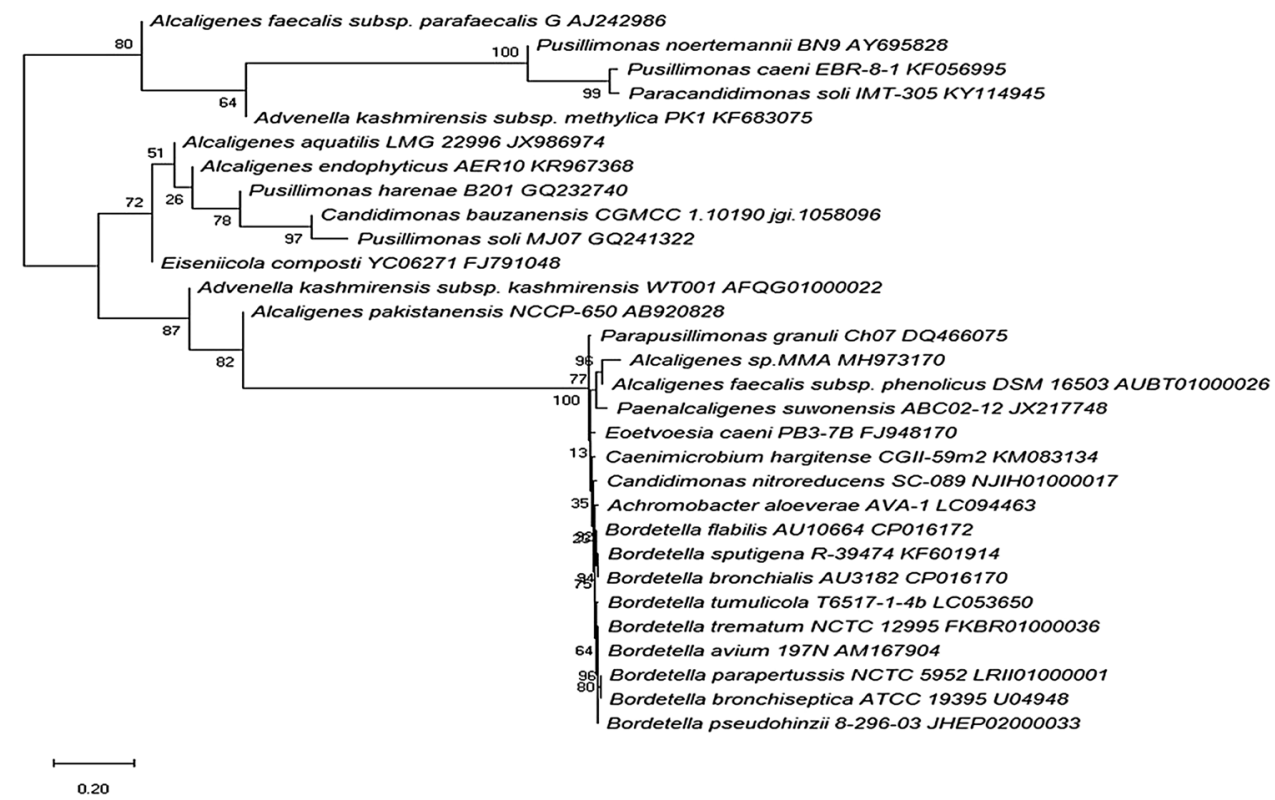

Fig. 4 Metal removal by Alcaligenes sp. MMA in $72 \mathrm{~h}$

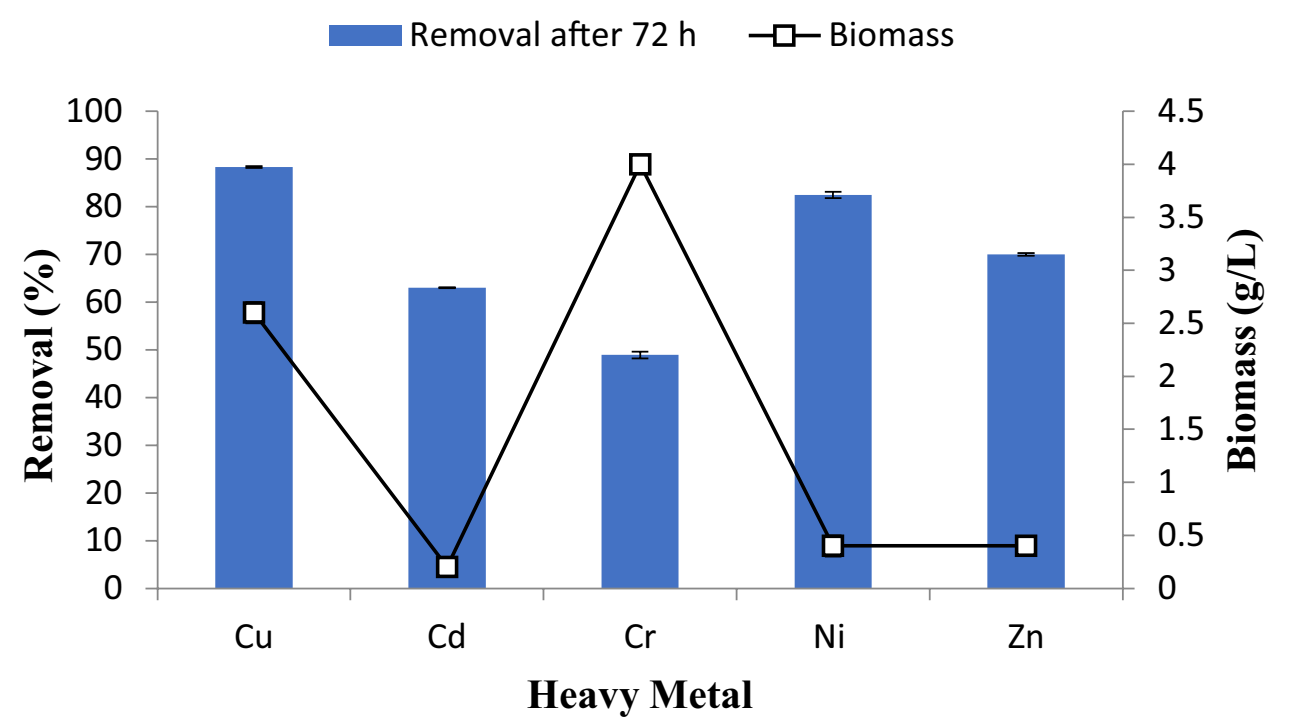

of Alcaligenes sp. MMA. Biomass produced in the case of $\mathrm{Cd}^{2+}$ is the least, which means $\mathrm{Cd}^{2+}$ is the most toxic out of the five metal for the bacterial strain but the metal removal was least in the case of $\mathrm{Cr}^{6+} \cdot \mathrm{pH}$ at the end of $72 \mathrm{~h}$ was also measured and was found to be 6.5, 6.2, 6.0,5.5, and 5.2, for $\mathrm{Cu}^{2+}, \mathrm{Ni}^{2+}, \mathrm{Zn}^{2+}, \mathrm{Cd}^{2+}$, and $\mathrm{Cr}^{6+}$, respectively. The $\mathrm{pH}$ of the growth medium can influence the metal removal, $\mathrm{pH}$ controls the metal ion solubility in the medium, along with the functional group speciation present on the cell wall of the bacteria. It can be noted that $\mathrm{pH}$ is in the optimum range for the $\mathrm{Cu}^{2+}$ and $\mathrm{Ni}^{2+}$, hence maximum removal is observed. In the case of $\mathrm{Cd}^{2+}$, the $\mathrm{pH}$ is low which means more $\mathrm{H}+$ ions in the solution which might saturate the bacterial cell wall and generating a positive charge on the cell wall of the bacteria, so there is a repulsive force for the metal cations which are present in the medium, hence low removal can be observed.

There is no universal trend followed between the growth of bacterial cells in terms of biomass and the removal of metals. This is mainly due to the affinity of the metals to the bacterial biomass which influences the uptake by the bacterial cell. In the biotic control, in the absence of any metal stress, the lag phase was limited to only $2 \mathrm{~h}$ and was very short as compared to the 6-8 $\mathrm{h}$ in heavy metal stress (Fig. 5). Table 3 shows the biomass, metal removal, and the specific uptake capacity (qm) (mg/g) of the Alcaligenes sp. MMA. Most of the heavy metal removal is seen in the exponential phase. No significant 
metal removal was observed after $48 \mathrm{~h}$. The specific uptake capacity was also calculated for the strain for different metals. An extended lag phase is observed in the case of $\mathrm{Cd}^{2+}$ and $\mathrm{Cr}^{6+}$ stress. The increase in the lag phase is due to the bacterial adaptation to the stress conditions. $\mathrm{Cr}^{6+}$ and $\mathrm{Cd}^{2+}$ being extremely toxic to the bacteria have an extended lag phase of 6-8 $\mathrm{h}$. The lag phase supports the formation of metabolic enzymes to support the growth of the bacteria and its adaptation to the stress medium. The lag phase depends on the morphology of the bacteria, the composition of the media, and the amount of inoculum. The low production of biomass in the case of $\mathrm{Cd}^{2+}$ is due to the slower metabolic activities of the bacteria in the stressed conditions. $\mathrm{Cd}^{2+}$ and $\mathrm{Cr}^{6+}$ are extremely toxic to the bacteria at $20 \mathrm{mg} / \mathrm{L}$.

The specific uptake capacity $\left(q_{\mathrm{m}}\right)$ at $20 \mathrm{mg} / \mathrm{L}$ was highest in the case of $\mathrm{Cd}^{2+}$ and least for $\mathrm{Cr}^{6+}$. The uptake of metals can be both on the surface of the bacterial cell or in the solution. It could be either extracellular accumulation/ precipitation, intracellular accumulation, and cell surface sorption/precipitation. In the case of bioaccumulation experiments, the supernatant and pellets are separated, the supernatant is subjected to digestion, then followed by AAS, whereas the pellet is subjected to gravimetric analysis [1]. Further, this is dependent on the bacterial cell metabolism if the bacterial cell in the presence of heavy metals stress produces certain compounds which favor the precipitation reaction. Biosorption is used extensively in recent years for heavy metals removal. Bacteria and algae have been used as biosorbents. In the case of multi-metals, adsorption of different metals on the surface of the adsorbent takes place simultaneously. In the environment and industries, heavy metals co-exist in the same place, therefore the microbes can survive and tolerate the different
Table 3 Biomass, metal removal, and specific uptake capacity of Alcaligenes sp. MMA in heavy metals stress

\begin{tabular}{llll}
\hline Heavy metal & Biomass $(\mathrm{g} / \mathrm{L})$ & $\begin{array}{l}\text { Metal } \\
\text { removal } \\
(\%)\end{array}$ & $\begin{array}{l}\text { Specific uptake } \\
\text { capacity }\left(q_{m}\right) \\
(\mathrm{mg} / \mathrm{g})\end{array}$ \\
\hline $\mathrm{Cu}(\mathrm{II})$ & 2.6 & 88.35 & 6.796 \\
$\mathrm{Cd}(\mathrm{II})$ & 0.2 & 63.04 & 57.455 \\
$\mathrm{Cr}(\mathrm{VI})$ & 0.4 & 48.93 & 0.61 \\
$\mathrm{Ni}(\mathrm{II})$ & 4 & 82.25 & 39.95 \\
$\mathrm{Zn}(\mathrm{II})$ & 0.4 & 69.99 & 34.925 \\
\hline
\end{tabular}

metal mixture [9]. The removal of multi-metal by single species biomass depends on the concentration and number of metals competing for binding to the active site [7]. Biosorption technology can be used in a pilot scale. At the industrial level, various bioreactors have been designed for the removal of heavy metals. The packed bed column was used to treat the wastewater using the olive tree pruning. This is effective in the treatment of heavy metals at a low cost. Packed bed column was used with an increased flow rate, decreased breakthrough time, exhaustion time, and the removal efficiency of nearly $99 \%$ was achieved $[27,33]$. Biosorption can also be used for the recovery and recycling of heavy metals. Prior to the recovery of heavy metals from aqueous solution, the individual metal ions must get separated from the solution. Zoogloea ramigera, a bacterium found mainly in activated sludge can be used as a biosorbent for elution of metals. $\mathrm{Ni}^{2+}$ and $\mathrm{Cd}^{2+}$ can be adsorbed using $\mathrm{HCl}$ and citrate solution [41]. Tang et al. [39] showed the recovery of $\mathrm{Pb}^{2+}$ from wastewater using precipitation and biosorption. Modified sugarcane bagasse is used for the selective adsorption of $\mathrm{Pb}^{2+}$ from a mixture of solution containing $\mathrm{Zn}^{2+}, \mathrm{Ca}^{2+}, \mathrm{Pb}^{2+}, \mathrm{Cd}^{2+}, \mathrm{Na}^{+}$, and $\mathrm{K}^{+}$. For the
Fig. 5 Growth curve of Alcaligenes sp. MMA in Biotic control and metal stress

\section{Growth curve of Alcaligenes sp. MMA in Biotic control and metal stress}

2

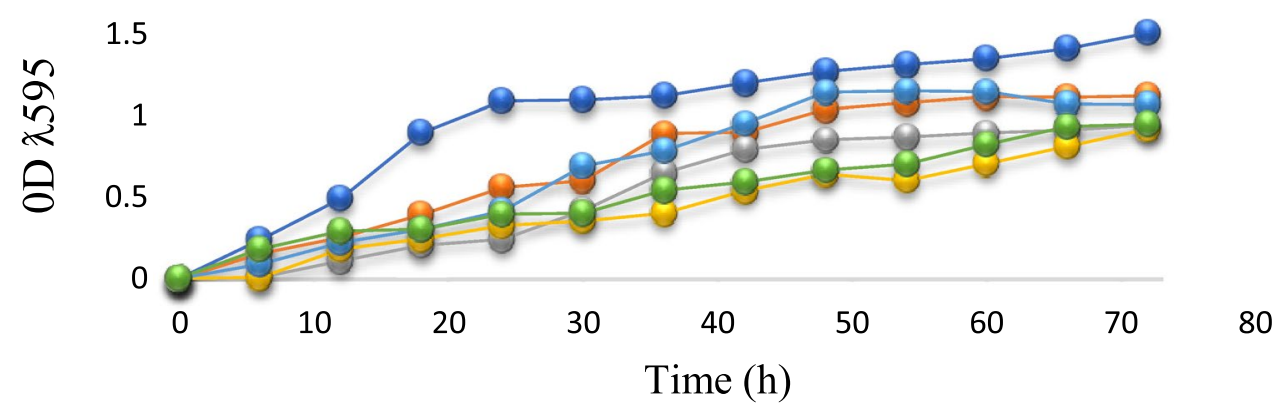

80 
desorption of $\mathrm{Pb}^{2+}, \mathrm{HNO}_{3}$ was used with $98 \%$ recovery, and $\mathrm{Na}_{3} \mathrm{PO}_{4}$ was used as a most efficient precipitant [39]. Ali et al. [4], reviewed the magnetotactic bacteria efficiency to bind metals. The nanosized magnetosomes (magnetite crystals) aids in biosorption by providing them with the ability to move along the externally applied magnetic field. The sorption is reversible and fast [4]. Vishan et al. [40] showed that the dried biomass of Bacillus badius AK can be used as a biosorbent for the recovery and removal of $\mathrm{Cd}^{2+}$ from aqueous solutions under optimum conditions. In this study, the desorption of the metal was carried out, regeneration of the biosorbent was done by washing with distilled water, followed by another cycle of biosorption. Different desorbents such as $\mathrm{HCl}, \mathrm{CH}_{3} \mathrm{COOH}$, EDTA, and $\mathrm{H}_{2} \mathrm{SO}_{4}$ can be used. The biosrorbent becomes loaded with metal, and the attached metal can be recovered for re-using the biomass $[25,40]$. Nanoparticles that are synthesized from the plants and microbes aids in metal removal by the process of bioremediation via adsorption, redox reaction, and photo-catalysis. Dendrimers, metal nanoparticles, carbon nanotube (CNT) can be employed as nanoparticles for the remediation of wastewater [37].

\subsection{Morphological results}

\subsubsection{SEM-EDX}

The SEM images showed a change in the morphology of metal-laden cells as compared to the control. The bacterial cells in control appeared uniform in shape, clear, and loosely packed having smooth outer surfaces but after biosorption of $\mathrm{Cd}^{2+}$ and $\mathrm{Cr}^{6+}$, there is a clear deformation in the bacterial cell wall, were densely packed with a lot of aggregation and roughness (Fig. 6). The possible reason for the roughness and wrinkling of the cells could be due to sequestration and precipitation of the functional groups [12]. The shape of the Alcaligenes in $\mathrm{Zn}^{2+}$ laden cells was preserved. In $\mathrm{Cu}^{2+}$ stress, the bacterial cell shows the accumulation of the heavy metal at the periphery, whereas in $\mathrm{Ni}^{2+}$ stress the accumulation was seen along with the deformation of the bacterial cell wall [43]. The SEM images show that metal ions induce a severe change in the morphology of the bacterial cell along with the toxicity. Similar results were obtained for Burkholderia sp. by Wei-Hua et al., 2009. In control, the integrity of the bacterial cell wall is maintained; however, a clear deformation is observed in the bacterial cell in stress conditions. The aggregation of the bacterial cells might be in response to heavy metal stress. Reports by Chakravarty and Banerjee [8] also showed the irregular electron-dense area and overlapping of the bacterial cells. $\mathrm{Zn}^{2+}$ has lesser or almost no effect on bacterial cell morphology which is also supported by the reports of Chakravarty and Banerjee. $\mathrm{Zn}^{2+}$ laden cell shows lesser aggregation and the cell shape was preserved, however, in the $\mathrm{Cu}^{2+}$ stress, there is heavy metal accumulation at the periphery whereas in $\mathrm{Ni}^{2+}$ stress, the deformation of the bacterial cell wall
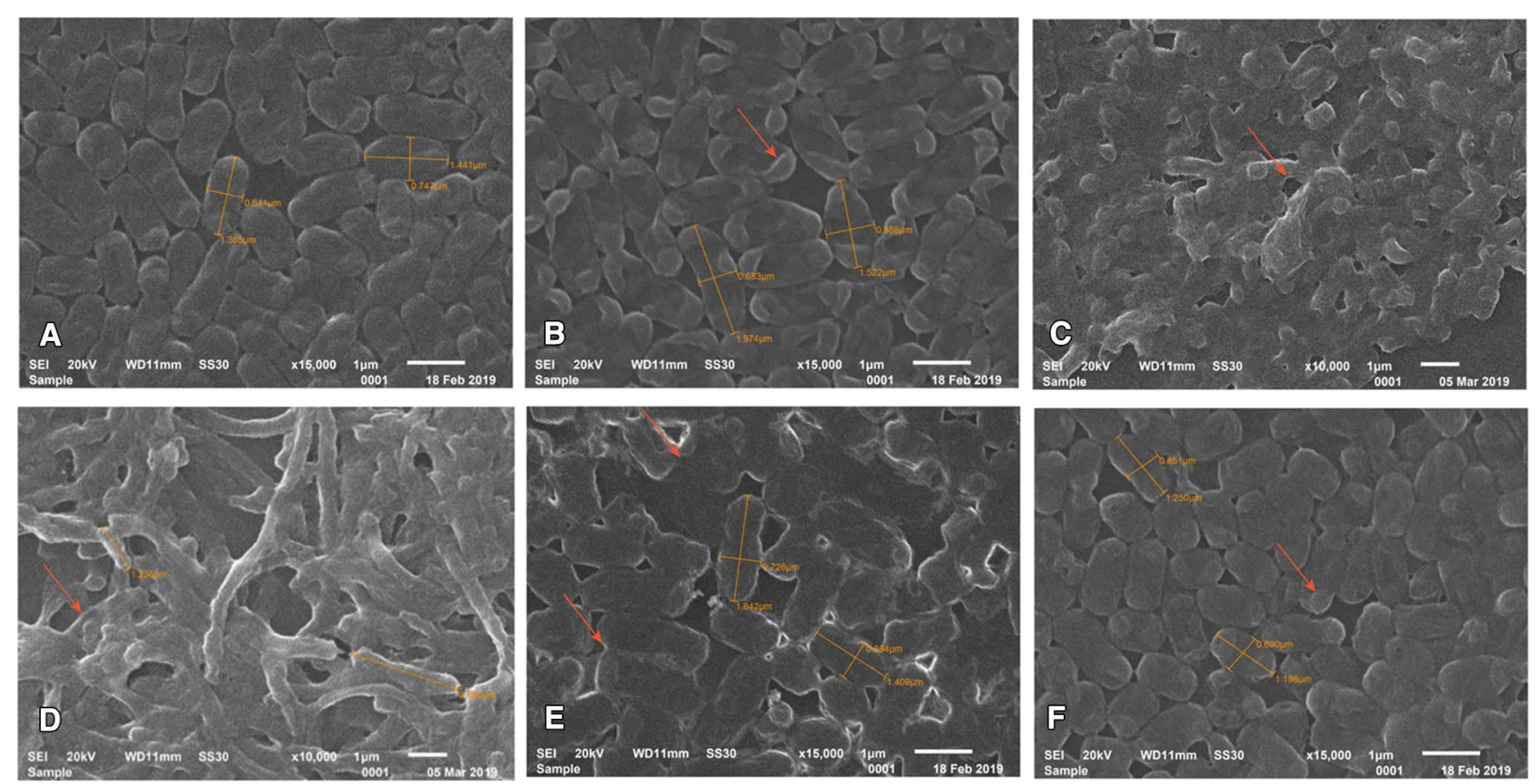

Fig. 6 Scanning electron micrographs of Alcaligenes sp. MMA in a metal absence (biotic control). b-f at $20 \mathrm{mg} \mathrm{L}{ }^{-1}$ of $\mathrm{Cu}$ (II), $\mathrm{Cd}$ (II), $\mathrm{Cr}(\mathrm{VI}), \mathrm{Ni}$ (II) and Zn (II). Scale $1 \mu \mathrm{m}$

\section{SN Applied Sciences}




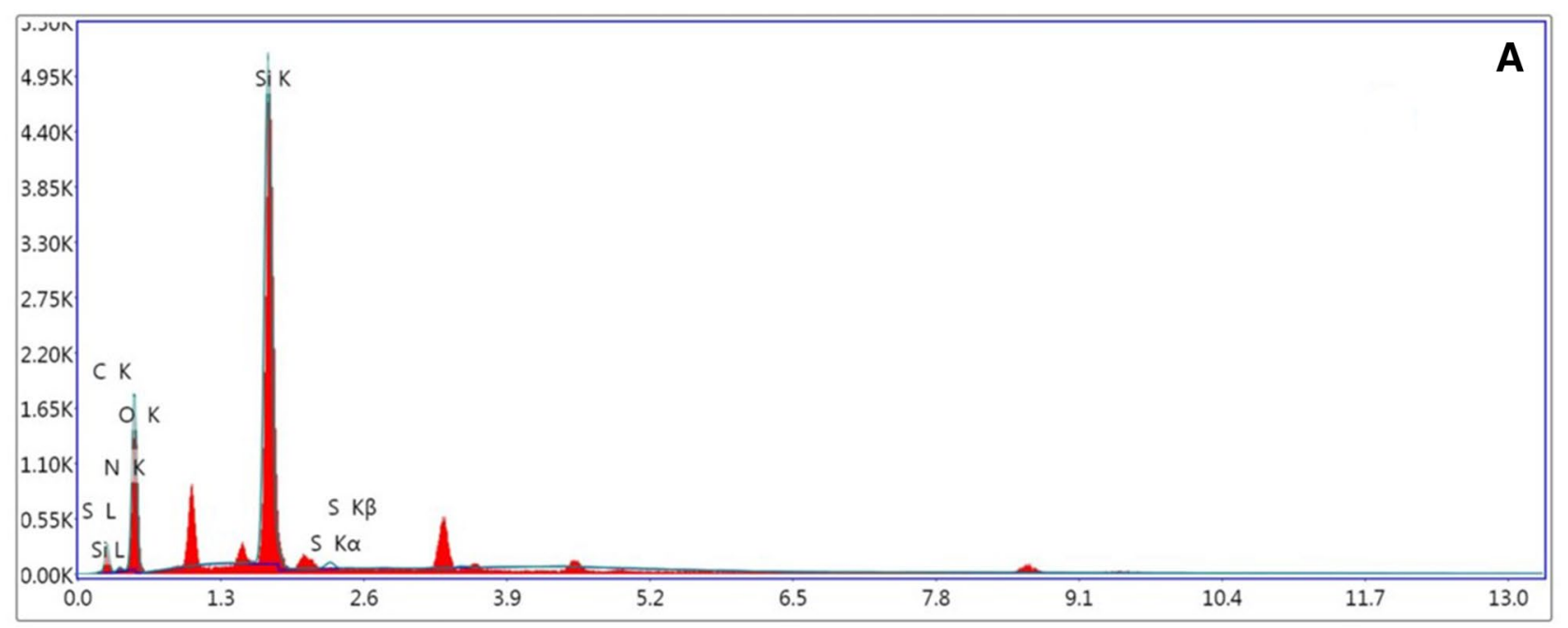

Lsec: 100.00 Cnts 0.000 keV Det: Octane Plus Det

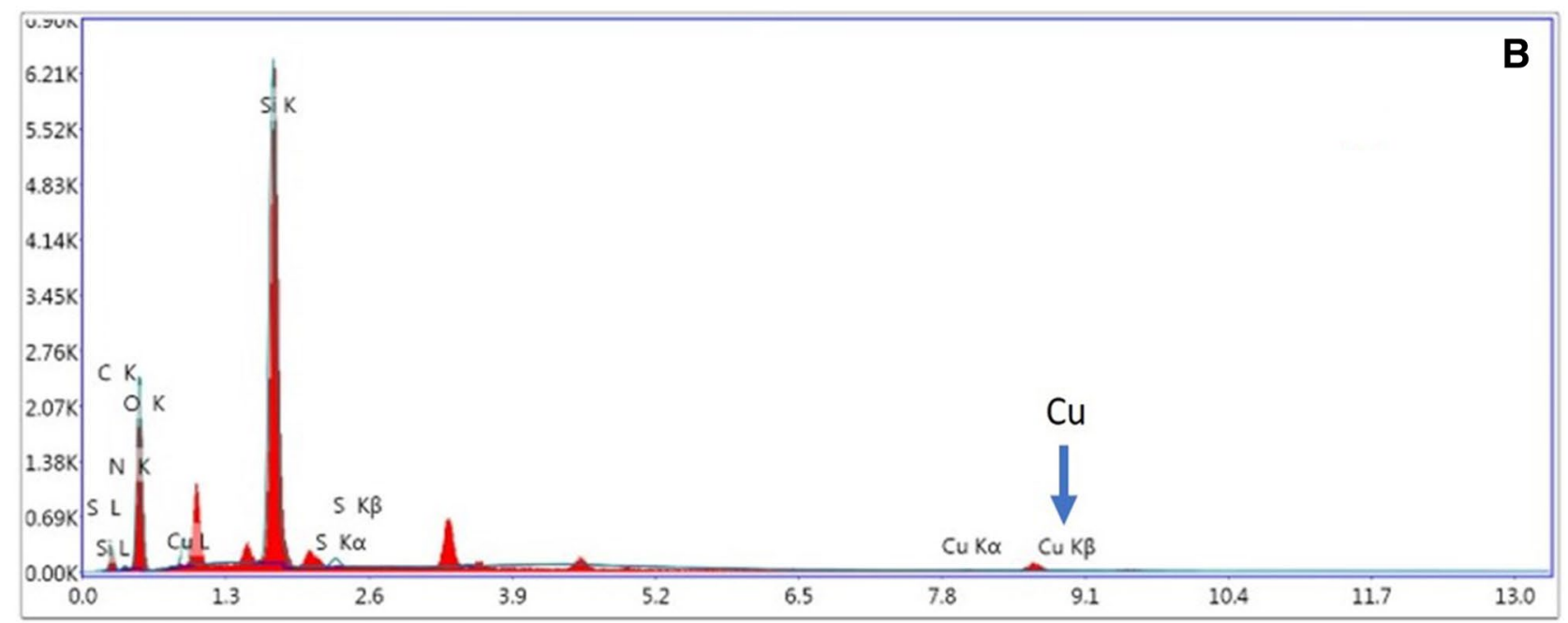

Lsec: 100.00 Cnts $0.000 \mathrm{keV}$ Det: Octane Plus Det

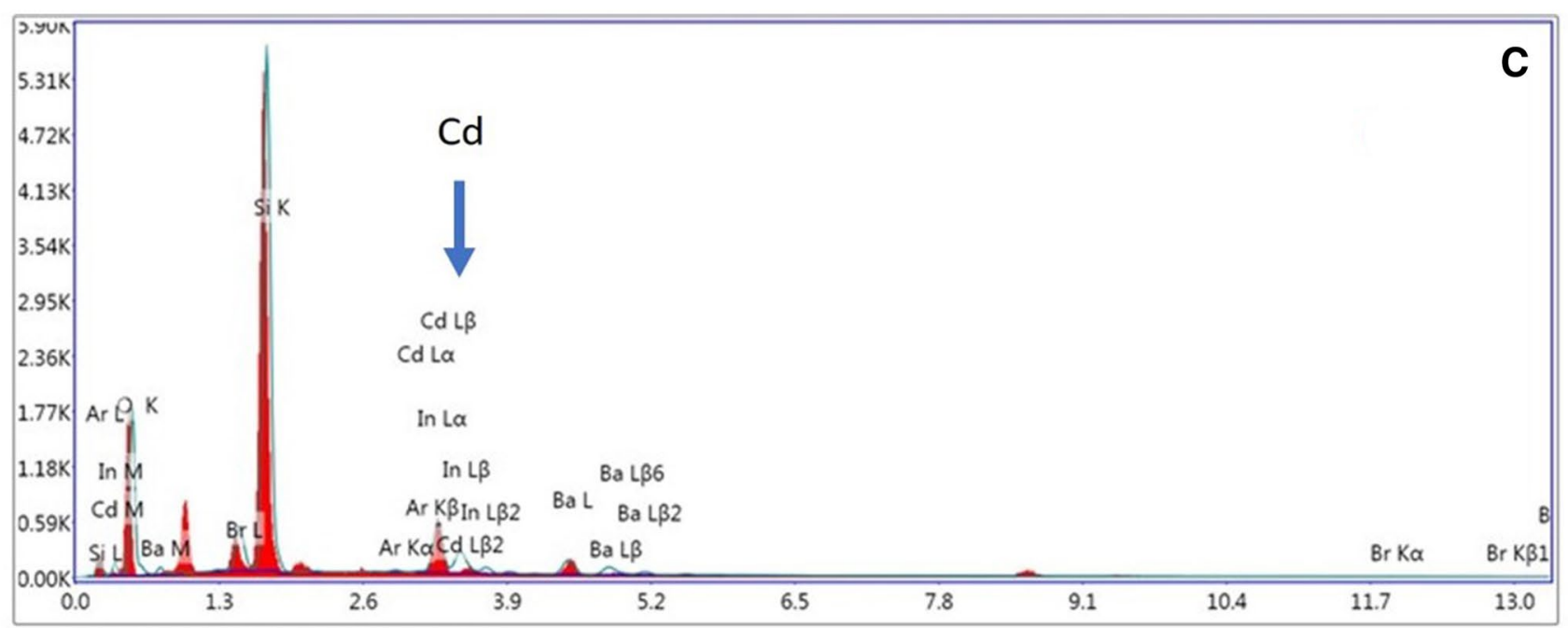

Lsec: 100.00 Cnts 0.000 keV Det: Octane Plus Det

Fig. 7 EDX micrograph confirming the presence of the metals 


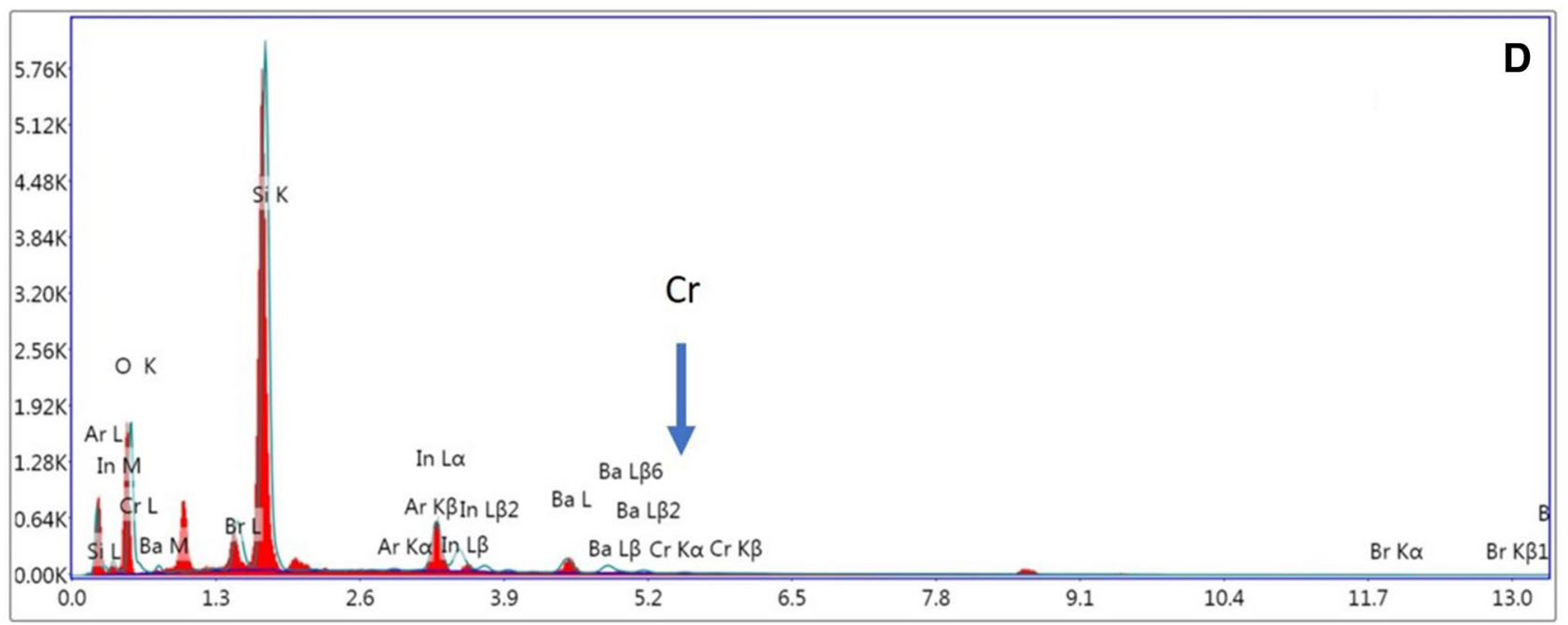

Lsec: 100.00 Cnts $0.000 \mathrm{keV}$ Det: Octane Plus Det

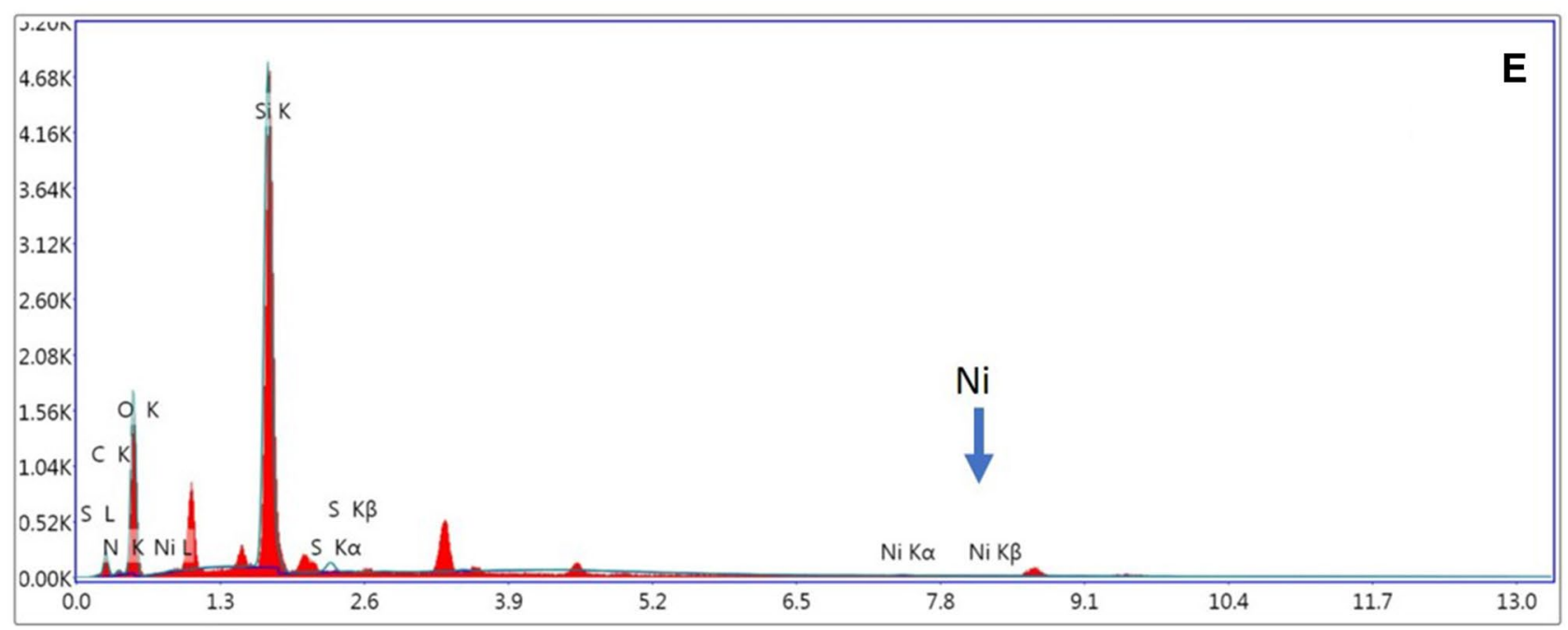

Lsec: 100.00 Cnts 0.000 keV Det: Octane Plus Det

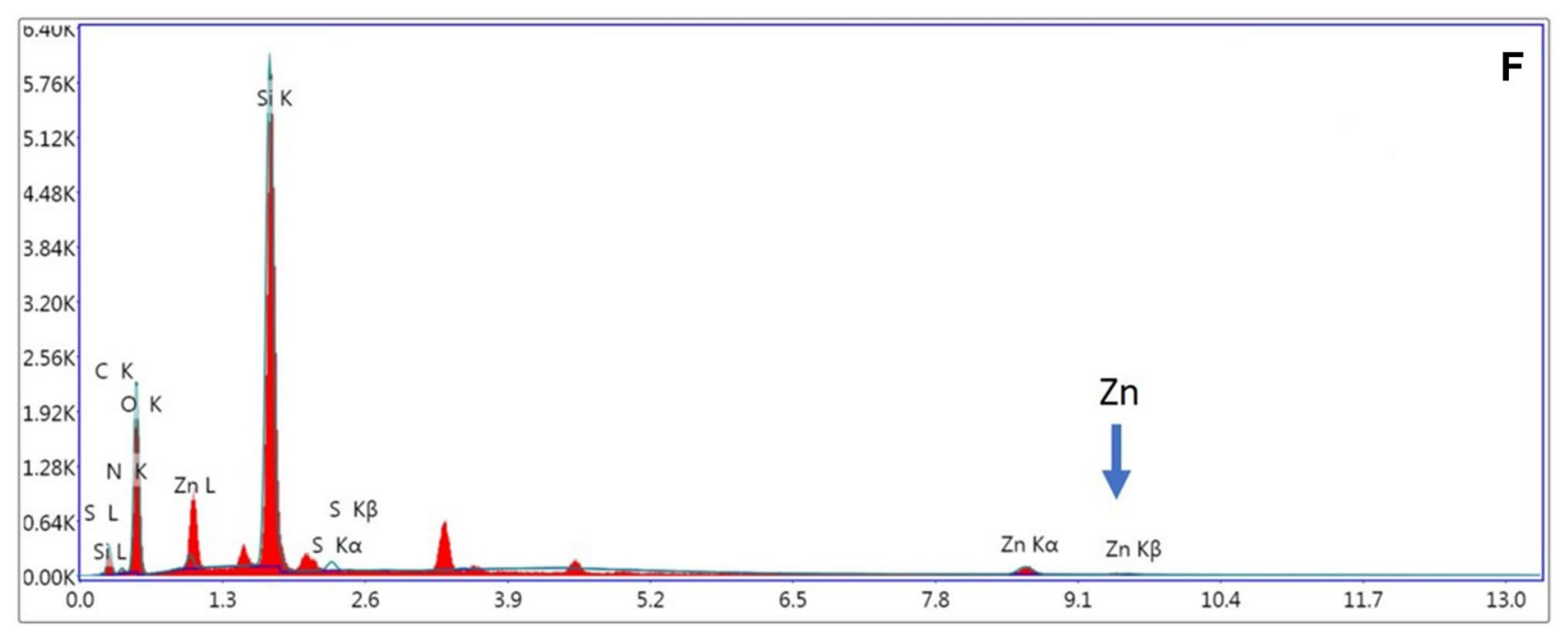

Lsec: 100.00 Cnts 0.000 keV Det: Octane Plus Det

Fig. 7 (continued)

\section{SN Applied Sciences}

A SPRINGER NATURE journal 
is seen along with the accumulation at the periphery", [43]. The aggregation of the bacterial cells is due to the bacterial stress response, to decrease the surface area for the accumulation of the metals. The entomopathogenic fungi Beauveria bassiana showed the aggregation and shortening of hyphae in $\mathrm{Pb}^{2+}$ laden cells [21]. EDX graph of bacterial biomass further confirms the presence of the metals on the bacterial cell surface (Fig. 7). The alkali earth metals peaks were also observed along with the metal peaks $\left(\mathrm{Cu}^{2+}, \mathrm{Cd}^{2+}, \mathrm{Cr}^{6+}, \mathrm{Ni}^{2+}\right.$, and $\left.\mathrm{Zn}^{2+}\right)$. The significant peaks of $\mathrm{Cu}^{2+}, \mathrm{Cd}^{2+}, \mathrm{Cr}^{6+}, \mathrm{Ni}^{2+}$, and $\mathrm{Zn}^{2+}$ are shown in Fig. 7.

\subsubsection{FTIR}

The FTIR spectra both in the control as well as in the presence of heavy metal were obtained in the range of $500-4000 \mathrm{~cm}^{-1}$. FTIR spectra identify the functional groups present on the surface of bacteria and their interaction with the heavy metals (Fig. 8). The spectra of control biomass and metal-laden cells show a prominent peak at $3407 \mathrm{~cm}^{-1}$ pertaining to $\mathrm{COOH}$ and $\mathrm{OH}$ group, amines and amides, At $2924.7 \mathrm{~cm}^{-1}$, the intensities of the peak of $\mathrm{Cd}^{2+}$ and $\mathrm{Cr}^{6+}$ is low, this might be due to the low concentration of the active bond, i.e, the functional group present, and the different vibrations of the functional groups in the molecule give rise to bands of differing intensity. The peak corresponds to $\mathrm{CAH}$ stretching. As compared to control, in the metal-laden cells especially in the $\mathrm{Cd}^{2+}$ and
$\mathrm{Cr}^{6+}$ laden cells, shifting of the peaks was observed. A new peak is observed in the range of $2100-2200 \mathrm{~cm}^{-1}$, corresponding to $\mathrm{C}=\mathrm{N}$ in $\mathrm{Cr}^{6+}$ laden cells. The shift in the peak corresponding to the $\mathrm{S}-\mathrm{C}$ bond around $500-700 \mathrm{~cm}^{-1}$ is observed in metal-laden cells. The presence of new peaks was observed along with shifting and masking of functional groups, i.e., amines, alkanes alkyl halides. Studies performed by Bahari et al. [5], Giri et al. [19] for Bacillus cereus cells when treated with arsenite and Escherichia coli cells exposed to $\mathrm{Cd}^{2+}, \mathrm{Cr}^{6+}, \mathrm{Ni}^{2+}$, and $\mathrm{Fe}^{3+}$ also showed -OH group complexation with the metal ions [26]. The result indicates that the hydroxyl, carboxyl, and amide are the dominant groups which are involved in biosorption.

\section{Conclusion}

Increased industrialization has contributed mainly to the pollution of metals. The recalcitrance of these compounds leads to their accumulation in the environment. The industrial discharge of the heavy metals directly into the water bodies results in their entry into the food chain. The use of this water directly for irrigational purposes leads to the contamination of the crops with heavy metals. The present study aimed to investigate the multi-metal resistant bacterial strain, present in the Yamuna River, its characterization and to study the bioaccumulation potential of the bacterial strain. SEM and FTIR studies were done for studying the morphological

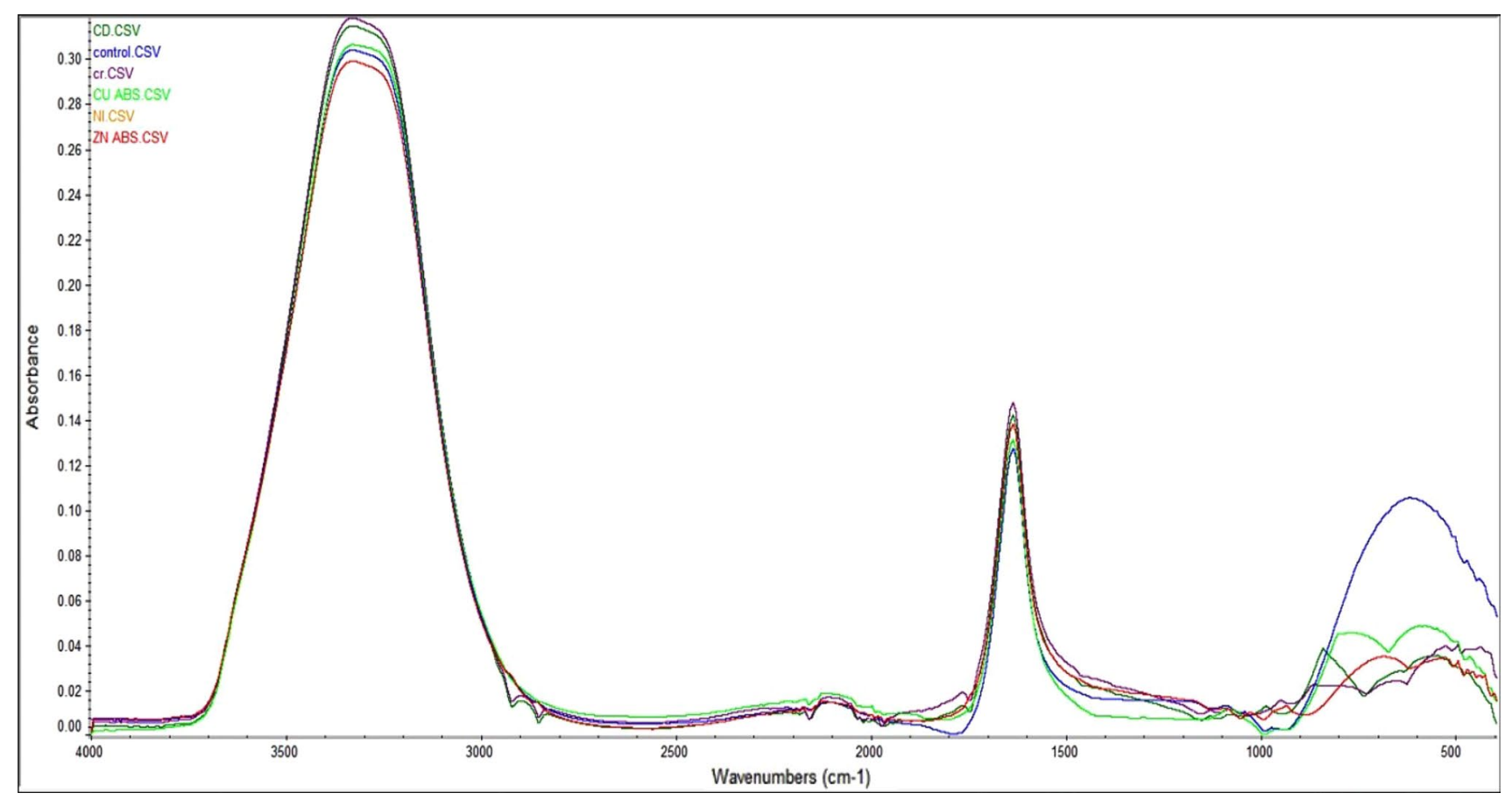

Fig. 8 FT-IR spectra showing the absorbance of the bacterial biomass in the absence of metal and in metal laden cells $\left(20 \mathrm{mg} \mathrm{L}^{-1}\right)$ 
changes induced upon metal stress. This study establishes multiple heavy metals removal by Alcaligenes sp. The bioaccumulation of the heavy metals by the bacterial strain was seen and the metal removal was in the range of (44-88\%). The effect of heavy metal was seen on the metal uptake by Alcaligenes sp. MMA. FTIR and SEM investigations further reveal the morphological changes induced by heavy metals. $\mathrm{Cr}^{6+}$ induces severe toxicity to the Alcaligenes sp. MMA and is also removed the least by the bacterial strain MMA. Along with $\mathrm{Cr}^{6+}$, $\mathrm{Cd}^{2+}$ also exerts toxicity to the Alcaligenes sp. the morphology of the bacterial cell is not uniform and the cell wall disruption is seen clearly, similarly in $\mathrm{Cd}^{2+}$ and $\mathrm{Cr}^{6+}$ laden cells a depression in the amide peak was seen in FTIR. The assessment of the River Yamuna was carried out which shows the $\mathrm{Cd}^{2+}$ and $\mathrm{Cr}^{6+}$ is present above the permissible limit as laid down by FAO, whereas the $\mathrm{Cu}^{2+}$ and $\mathrm{Zn}^{2+}$ were detected within the permissible limits and $\mathrm{Ni}^{2+}$ remains undetected in the three seasons. Further study should focus on the whole-cell protein extraction of bacterial cells for studying the differential expression of genes under metal stress. Pilot-scale applications of biosorption are already under consideration for heavy metal removal. Emerging technologies such as the use of biologically synthesized nanomaterials for heavy metal removal should be considered. Biosorption is a sustainable and promising technology, which makes the reuse of heavy metal feasible.

Acknowledgements Financial assistance provided by the NASF research grant (project entitled "Bioremediation of chemical contaminants and their complexes present in drainage water with high dynamic flux used for irrigation in urban and peri-urban agriculture"), sanction no. NASF/CA-6030/2017-18 is highly acknowledged. The author Kushneet Kaur Sodhi highly acknowledges the University Grant Commission (UGC), Government of India for providing the stipend and MK would like to thank Hindu college (DU) for providing the infrastructural facility and funds for the ongoing innovation project (SC/2019-2020/05 and SC/2019-2020/06). DKS particularly acknowledge the NASF (ICAR) for providing the funds for ongoing research, (NASF/CA-6030/2017-18).

Funding This study was supported by the funding agency, National Agricultural Science Fund, Indian Council of Agricultural Research, Delhi, India.

\section{Compliance with ethical standards}

Conflict of interest The authors declare that they have no conflict of interest.

\section{References}

1. Ahalya N, Ramachandra TV, Kanamadi RD (2003) Biosorption of heavy metals. Res J Chem Environ 7(4):71-79
2. Algarra $M$, Jiménez $M V$, Rodríguez-Castellón $E$, Jiménez-López A, Jiménez-Jiménez J (2005) Heavy metals removal from electroplating wastewater by aminopropyl-Si MCM-41. Chemosphere 59(6):779-786

3. Ayangbenro A, Babalola O (2017) A new strategy for heavy metal polluted environments: a review of microbial biosorbents. Int J Environ Res Public Health 14(1):94

4. Ali I, Peng C, Khan ZM, Naz I, Sultan M (2018) An overview of heavy metal removal from wastewater using magnetotactic bacteria. J Chem Technol Biotechnol 93(10):2817-2832

5. Bahari ZM, Altowayti WAH, Ibrahim Z, Jaafar J, Shahir S (2013) Biosorption of As (III) by non-living biomass of an arsenichypertolerant Bacillus cereus strain SZ2 isolated from a gold mining environment: equilibrium and kinetic study. Appl Biochem Biotechnol 171(8):2247-2261

6. Bhattacharya A, Dey P, Gola D, Mishra A, Malik A, Patel N (2015) Assessment of Yamuna and associated drains used for irrigation in rural and peri-urban settings of Delhi NCR. Environ Monit Assess 187(1):4146

7. Bueno BYM, Torem ML, Molina FALMS, De Mesquita LMS (2008) Biosorption of lead (II), chromium (III) and copper (II) by R. opacus: equilibrium and kinetic studies. Miner Eng 21(1):65-75

8. Chakravarty R, Banerjee PC (2008) Morphological changes in an acidophilic bacterium induced by heavy metals. Extremophiles 12(2):279-284

9. Choińska-Pulit A, Sobolczyk-Bednarek J, Łaba W (2018) Optimization of copper, lead and cadmium biosorption onto newly isolated bacterium using a Box-Behnken design. Ecotoxicol Environ Saf 149:275-283

10. Colpaert JV, Van Assche JA (1992) Zinc toxicity in ectomycorrhizal Pinus sylvestris. Plant Soil 143(2):201-211

11. CPCB (Central Pollution Control Board) Status of sewerage and sewage treatment plants in Delhi. CVPS/57/2004-05

12. Dadrasnia A, Chuan Wei KS, Shahsavari N, Azirun MS, Ismail S (2015) Biosorption potential of Bacillus salmalaya strain 139SI for removal of $\mathrm{Cr}(\mathrm{VI})$ from aqueous solution. Int J Environ Res Public Health 12(12):15321-15338

13. De J, Ramaiah N, Vardanyan L (2008) Detoxification of toxic heavy metals by marine bacteria highly resistant to mercury. Mar Biotechnol 10(4):471-477

14. del Carmen Vargas-Garcia M, López MJ, Suárez-Estrella F, Moreno J (2012) Compost as a source of microbial isolates for the bioremediation of heavy metals: in vitro selection. Sci Total Environ 431:62-67

15. Dey P, Gola D, Mishra A, Malik A, Kumar P, Singh DK, Jehmlich $\mathrm{N}$ (2016) Comparative performance evaluation of multi-metal resistant fungal strains for simultaneous removal of multiple hazardous metals. J Hazard Mater 318:679-685

16. Fashola MO, Ngole-Jeme VM, Babalola OO (2016) Heavy metal pollution from gold mines: environmental effects and bacterial strategies for resistance. Int J Environ Res Public Health 13(11):1047

17. Gadd GM (1992) Metals and microorganisms: a problem of definition. FEMS Microbiol Lett 100(1-3):197-203

18. Gall JE, Boyd RS, Rajakaruna N (2015) Transfer of heavy metals through terrestrial food webs: a review. Environ Monit Assess 187(4):201

19. Giri AK, Patel RK, Mahapatra SS, Mishra PC (2013) Biosorption of arsenic (III) from aqueous solution by living cells of Bacillus cereus. Environ Sci Pollut Res 20(3):1281-1291

20. Gola D, Dey P, Bhattacharya A, Mishra A, Malik A, Namburath $M$, Ahammad SZ (2016) Multiple heavy metal removal using an entomopathogenic fungi Beauveria bassiana. Bioresour Technol 218:388-396

21. Gola D, Malik A, Namburath M, Ahammad SZ (2018) Removal of industrial dyes and heavy metals by Beauveria bassiana: 
FTIR, SEM, TEM and AFM investigations with $\mathrm{Pb}(\mathrm{II})$. Environ Sci Pollut Res 25(21):20486-20496

22. Hassen A, Saidi N, Cherif M, Boudabous A (1998) Resistance of environmental bacteria to heavy metals. Bioresour Technol 64(1):7-15

23. Holt JG, Williams ST (1989) Holt: Bergey's manual of systematic bacteriology, vol 4. Lippincott Williams \& Wilkins, Philadelphia

24. Huang HJ, Yuan XZ (2016) The migration and transformation behaviors of heavy metals during the hydrothermal treatment of sewage sludge. Bioresour Technol 200:991-998

25. Kaushik P, Mishra A, Malik A, Pant KK (2014) Biosorption of textile dye by Aspergillus lentulus pellets: process optimization and cyclic removal in aerated bioreactor. Water Air Soil Pollut 225(6):1978

26. Kumari V, Yadav A, Haq I, Kumar S, Bharagava RN, Singh SK, Raj A (2016) Genotoxicity evaluation of tannery effluent treated with newly isolated hexavalent chromium reducing Bacillus cereus. J Environ Manag 183:204-211

27. Kumari N, Rana A, Jagadevan S (2019) Arsenite biotransformation by Rhodococcus sp.: characterization, optimization using response surface methodology and mechanistic studies. Sci Total Environ 687:577-589

28. Morais S, Costa FG, Pereira MDL (2012) Heavy metals and human health. Environ Health Emerg Issues Pract 10:227-246

29. Nguyen TAH, Ngo HH, Guo WS, Zhang J, Liang S, Yue QY, Nguyen TV (2013) Applicability of agricultural waste and byproducts for adsorptive removal of heavy metals from wastewater. Bioresour Technol 148:574-585

30. Nies DH, Silver S (1995) Ion efflux systems involved in bacterial metal resistances. J Ind Microbiol 14(2):186-199

31. Niu Y, Jiang X, Wang K, Xia J, Jiao W, Niu Y, Yu H (2020) Meta analysis of heavy metal pollution and sources in surface sediments of Lake Taihu, China. Sci Total Environ 700:134509

32. Ramos-Rosas NN, Valdespino C, García-Hernández J, GalloReynoso JP, Olguín EJ (2013) Heavy metals in the habitat and throughout the food chain of the Neotropical otter, Lontra longicaudis, in protected Mexican wetlands. Environ Monit Assess 185(2):1163-1173

33. Ronda A, Martín-Lara MA, Osegueda O, Castillo V, Blázquez G (2018) Scale-up of a packed bed column for wastewater treatment. Water Sci Technol 77:1386-1396

34. Saitou N, Nei M (1987) The neighbor-joining method: a new method for reconstructing phylogenetic trees. Mol Biol Evol 4(4):406-425
35. Sharma R, Singh NS, Singh DK (2019) Soil microbial diversity of peri-urban agricultural field and riverbank along Yamuna river in Delhi, India. SN Appl Sci 1(1):22

36. Singh $H$, Rathore RS, Singh S, Cheema PS (2011) Comparative analysis of cultural isolation and PCR based assay for detection of Campylobacter jejuni in food and faecal samples. Braz J Microbiol 42(1):181-186

37. Sudhakar MS, Aggarwal A, Sah MK (2020) Engineering biomaterials for the bioremediation: advances in nanotechnological approaches for heavy metals removal from natural resources. In: Emerging technologies in environmental bioremediation. Elsevier, pp 323-339

38. Tamura K, Nei M, Kumar S (2004) Prospects for inferring very large phylogenies by using the neighbor-joining method. Proc Natl Acad 101(30):11030-11035

39. Tang J, Xi J, Yu J, Chi R, Chen J (2018) Novel combined method ofbiosorption and chemical precipitation for recovery of $\mathrm{Pb} 2$ + from wastewater. Environ Sci Pollut Res 25:28705-28712

40. Vishan I, Saha B, Sivaprakasam S, Kalamdhad A (2019) Evaluation of $\mathrm{Cd}$ (II) biosorption in aqueous solution by using lyophilized biomass of novel bacterial strain Bacillus badius AK: biosorption kinetics, thermodynamics and mechanism. Environ Technol Innov 14:100323

41. Xie JZ, Chang HL, Kilbane JJ II (1996) Removal and recovery of metal ions from wastewater using biosorbents and chemically modified biosorbents. Bioresour Technol 57(2):127-136

42. Xie Y, Fan J, Zhu W, Amombo E, Lou Y, Chen L, Fu J (2016) Effect of heavy metals pollution on soil microbial diversity and bermudagrass genetic variation. Front Plant Sci 7:755

43. Yilmazer P, Saracoglu N (2009) Bioaccumulation and biosorption of copper (II) and chromium (III) from aqueous solutions by Pichia stipitis yeast. J Chem Technol Biotechnol Int Res Process Environ Clean Technol 84(4):604-610

44. Yoon SH, Ha SM, Kwon S, Lim J, Kim Y, Seo H, Chun J (2017) Introducing EzBioCloud: a taxonomically united database of $16 \mathrm{~S}$ rRNA gene sequences and whole-genome assemblies. Int J Syst Evol Microbiol 67(5):1613

Publisher's Note Springer Nature remains neutral with regard to jurisdictional claims in published maps and institutional affiliations. 